\title{
Influence of human resources to the effect of system quality and information quality on the user satisfaction of accrual-based accounting system
}

\author{
Influencia de los recursos humanos en el efecto de la calidad del sistema y la \\ calidad de la información en la satisfacción del usuario del sistema contable \\ basado en valores devengados
}

\author{
Iskandar Muda*, Ade Afrina Erlina \\ Universitas Sumatera Utara, Indonesia
}

Received September 6, 2017; accepted November 24, 2018

Available online November 20, 2018

\begin{abstract}
The purpose of this study is to examine the effect of system quality and information quality on the User satisfaction of The Accrual-Based Accounting System of Institutions application moderated by Human Resources Quality in service partner work units of the Indonesia. The population of this study consisted of 209 work units. The sampling was conducted by using sensus method using the primary data collected through questionnaires. The data were then analyzed by using the Structural Equation Modelling-Partial Least Squares. The results showed that the quality of system, information, and human resources had a significant positive effect on the User satisfaction of Accrual-Based Accounting System of Institutions application. The Human Resources quality as the moderating variable was able to moderate the relationship between the system quality and information quality in the User satisfaction of Accrual-Based Accounting System of Institutions application.
\end{abstract}

Keywords: Accrual-Based Accounting System; System quality; Information Quality; Human Resources Quality; User Satisfaction; Institutions application.

\footnotetext{
* Corresponding author.

E-mail address: iskandar1@usu.ac.id (I. Muda)

Peer Review under the responsibility of Universidad Nacional Autónoma de México.
} 


\section{Resumen}

El propósito de este estudio es examinar el efecto de la calidad del sistema y la calidad de la información en la Satisfacción del Usuario por la aplicación en las Instituciones del Sistema de Contabilidad por Devengo moderadas por la calidad de los Recursos Humanos en las unidades de trabajo de socios de servicio en Indonesia. La población de este estudio consistió de 209 unidades de trabajo. La muestra se realizó con el uso del método sensus con datos básicos recolectados mediante cuestionarios. Los datos fueron luego analizados con el uso de Cuadrados Mínimos Parciales del Modelaje Estructural de Ecuaciones. Los resultados mostraron que la calidad del sistema, de la información y de los recursos humanos tenían un importante efecto positivo en la Satisfacción del Usuario por la aplicación en las Instituciones del Sistema Contable por Devengo. La calidad de los Recursos Humanos como la variable moderadora pudo moderar la relación de la calidad del sistema y la calidad de la información con la Satisfacción del Usuario por la aplicación en las Instituciones del Sistema Contable por Devengo.

Palabras claves: Sistema contable por devengo; Calidad del sistema; Calidad de la información; Calidad de los recursos humanos; Satisfacción del usuario; Aplicación en instituciones.

\section{Introduction}

The implementation of the Accrual-Based Government Accounting Standards in the ministries/institutions that began in 2015 by using the Accrual-Based Accounting System of Institutions Application. The stipulation of the regulation on the accrual-based Government Accounting Standards signed by the President required all government agencies, both at the central and regional levels, to implement the Accrual-Based Government Accounting Standards started from January 1, 2015. The legal basis of the accrual-based Government Accounting Standards is the Government Regulation Number 71 of 2010 on Government Accounting Standards. Accrual-Based Accounting System of Institutions Application is the development of the Accounting System of Proxy of Budget User which was used prior to 2015 by using the cashbased financial statements. The Accrual-Based Accounting System of Institutions application is still under development, so it often requires updates to update the existing features of the application. Given the change in the government accounting base from cash to accruals to a full accrual basis, the local financial management apparatus is required to develop an understanding in accounting. To get the competent apparatus in this field, this is not apart from the educational background, training and work experience that is owned by the financial management apparatus itself. Financial management apparatus that controls government accounting is needed in preparation and preparation of financial statements that must be prepared in an orderly manner following applicable government accounting standards. The financial statements are principally the regional government management assertions that contain and present complete financial information as a basis for the government to make economic and financial decisions and to fulfill the government's accountability aspects in managing regional finances according to the regulatory mandate entrusted to them (Eriadi et al., 2018; Muda and Naibaho, 2018 \& Muda and Hutapea, 2018). Regional government financial statements essentially contain all financial performance achievements during the accounting period regarding revenue and expenditure achievements, achievement of assets and liabilities growth and equity as well as a real picture of expenses and financing. 
The information system user satisfaction can be used as a measurement for the success of an information system. User satisfaction then becomes a part in the development model of the success of information system. The information system that meet the needs and expectations of the users is the high-quality information system, which is fast in displaying information, actual, can be used as a consideration in decision making and suitable to the desired needs. In order to meet the needs of a good information system, it requires a good design system, as well as a good programming system and is able to ease the user by providing and developing various facilities to access the information. The key to success in satisfying users of information system is in the quality of services provided by the information system providers. The benefits of information technology in building an individual, company, and even a country are very big impact. Proven that IT can change an Individual, a company, even an organization and country (Winter et al, 2009). The Information system success model that is widely used is the DeLone and McLean (2003) model which states that information quality, system quality and service quality will have a positive effect on user satisfaction Woodham et al., 2017; Hussain et al., 2017; Filieri et al., 2017; Lin, 2017; Efthymiou and Antoniou, 2017; Kim et al., 2017; Radu et al., 2017; Hong et al. 2017 Berger et al., 2017; Carrasco et al., 2017; Yousuf and Wahab, 2017; Laumer et al., 2017; Kiran and Diljit, 2017; Balaji et al., 2017; Yang, 2017; Noutsa et al., 2017; Ryu and Lee., 2017; Cleverley et al., 2017 and Kilsdonk et al., 2017. A study conducted by Iivari (2005) that empirically tested the DeLone and McLean model, proved that the success of information system is influenced by the quality of information system and the quality of information generated from the related system. Human resources as the application users have a direct connection with the implementation of the system. Therefore, the competence of application users is a very important factor in the successful implementation of information system. The challenges faced by human resource competencies are competency methods to meet significant future challenges. In order to utilize strategies based on efficient human resource development, the needs of organizational leaders and the needs of human resource practitioners to make a number of basic decisions may face several challenges. The role of human resource management has shifted from traditional management that only manages people in organizations, to strategic human resource management to make decisions according to environmental changes that are very fast and difficult to predict. The ability of managers or managers to balance organizational changes with internal factors and external factors is the key to the success of a business activity.

The purpose of this study is to support of the Adaptive Behavior Assessment System (ABAS) Theory where quality and information quality systems impact on the User satisfaction. Almost every organization activity is currently using technology. Information technology revolution occurs in organizational activities, from manual systems to computerized systems. Simple information systems can be said to be processing data and then transforming it into information. In simple terms it can be said that a system of information and processing data, and then turn it into information. The Information System involves all organizational components related to input (data) activities, output (information), and also users. Information flow in the organization flows vertically and horizontally. The information systems and human resources involved are very important components in the success of the organization both engaged in business and non-business. The most challenging task facing the organization is the effectiveness of implementing information technology. This role requires human resources who can absorb, understand and adapt with new things. Within the scope of the information 
technology requires the user to be adaptive to change and progress. Information systems will never develop by themselves, but need to be supported by many factors that can be effective. The success of the development of information systems depends very much on the suitability of expectations between systems analysts, users, sponsors and customers. The development of information systems requires careful planning and implementation, to avoid rejection of the system being developed. If the information system is used optimally, it can improve the quality of information and increase user satisfaction.

\section{Literature review}

\section{Adaptive Behavior Assessment System (ABAS) Theory}

Adaptive behavior is the level of ability/effectiveness of a person in meeting the standards of personal independence and social responsibility expected for age and group culture (American Association on Mental Deficiency/AAMD, 1983). Adaptive behavior is a person's self and social maturity in carrying out everyday activities in accordance with age and related to the culture of the group and adaptive behavior is self and social maturity (Gresham and Elliot, 1987; Rust et al, 2004; Krichmar, 2008; Oakland and Harrison, 2011; Price et al., 2018 and James et al., 2018). Someone in carrying out general daily activities in accordance with age conditions and related to group culture. The concept of adaptive behavior:

1. Adaptive behavior focuses on everyday behavior.

2. Fulfillment of the expectations of the community \& environment where the person concerned lives.

3. The ability to effectively cope with the conditions that are happening in the community.

The concept of social ability/adaptive behavior can be interpreted as a person's ability to master social speech in their environment. The ability to adapt to the demands of the environment or the application of new systems that are displayed in the form of capabilities:

1. Independent functioning/function of independence: ability to achieve success in carrying out tasks according to age and hope.

2. Personal responsibility: ability monitor his personal behavior and can accept all risks from a sense of responsibility for making a decision.

3. Social responsibility: social adjustment to the environment, emotional development, acceptance of feelings and responsibilities around it.

In the adaptive structure the technological characteristics of the technology are reflected in features and general spirit. The use of organizational resources in the form of regulations, 
values, agreements so as to bring about an appropriate use attitude towards the technology of consensus level between users. The assumptions, expectations, and knowledge of people about information technology affect the acceptance of information technology applications in an organization (Orlikowski and Gash, 1991; Karanasios, 2018). The gap in understanding between system users and system analysts arises due to gaps in cognitive frames. Every information processing is mediated by categorizers and imposition of concepts. These categories and concepts are actually is a model/imitation) about the world around. This model contains knowledge structures or cognition structures.

\section{The Information System Success Model}

Examining the success of an information system is an important thing for an organization which is implementing a new information system. DeLone \& McLean (1992) and Gao and Park (2017) proposed a model to measure the success of information system in organizational level. DeLone and McLean proposed a theory about the success of information system known as the Delone and McLeon success model which consists of:

1. System quality is used for measuring the quality of system of the information technology itself.

2. Information quality is used for measuring the output quality of the information system.

3. Use is the use of the output of a system by the receiver/user.

4. User satisfaction is the response provided by the user in response to the use of the output of information system.

5. Individual impact is the effect of information on user behavior.

6. Organizational impact is the effect of information on organizational performance.

Factors of success of information systems in an organization because of the quality characteristics of the system itself that can be replicated, the quality of the information system output, consumption of output, user response to the information system, the influence of information systems on user habits and their influence on organizational performance. system quality and information quality, individually and together, affect the satisfaction of its users. A quality information system that can meet the needs will satisfy its users and optimize the performance of users and their organizations so that the organization will support the information system technology.

\section{Human Resources (HR) Quality}

Human resources (HR) are the people who are in an organization who contribute through their thoughts and perform various jobs in achieving the organizational goals. The contribution is the thought that they have in various activities within the organization (Muda and Dharsuky, 2015, Mendoza et al., 2011; Cheuk et al., 2017; Iannacci and Comford, 2017; Achamad et al., 
2017; Zerbino et al. 2017; Tam et al., 2017; Hernandez-Ortega et al., 2017; Sánchez et al., 2017; Almazán et al., 2017; Alzahrani, et al., 2017; Shin et al., 2017; Horvath and Bauermeister, 2017; Hsu et al., 2017; Muda et al., 2018; Muda and Erlina, 2018 \& Pohan et al., 2018). The ability of the organization to deliver its goals is determined by the quality of human resources owned by the organization. Therefore, Human Resources is one of the important elements in the organization (Dalimunthe et al., 2016; 2017 and Gusnardi et al., 2016). Human resource development can basically be done in various ways, but in principle, it is to increase human resource competence. Development improvements can be done through education, training, motivation and various key human resource programs Human Resources is the main pillar which supports and drives the organization in the effort to realize the vision and mission of the organization. The key to success above depends on the human resource infrastructure as follows: 1. how is the readiness of human resources to achieve the desired results. 2 . how the right human with the right skills at the right place and the right cost. 3. Human resource needs. As well as the ability to adapt to changes to maintain humans who are ready for the next arrival

\section{Conceptual framework}

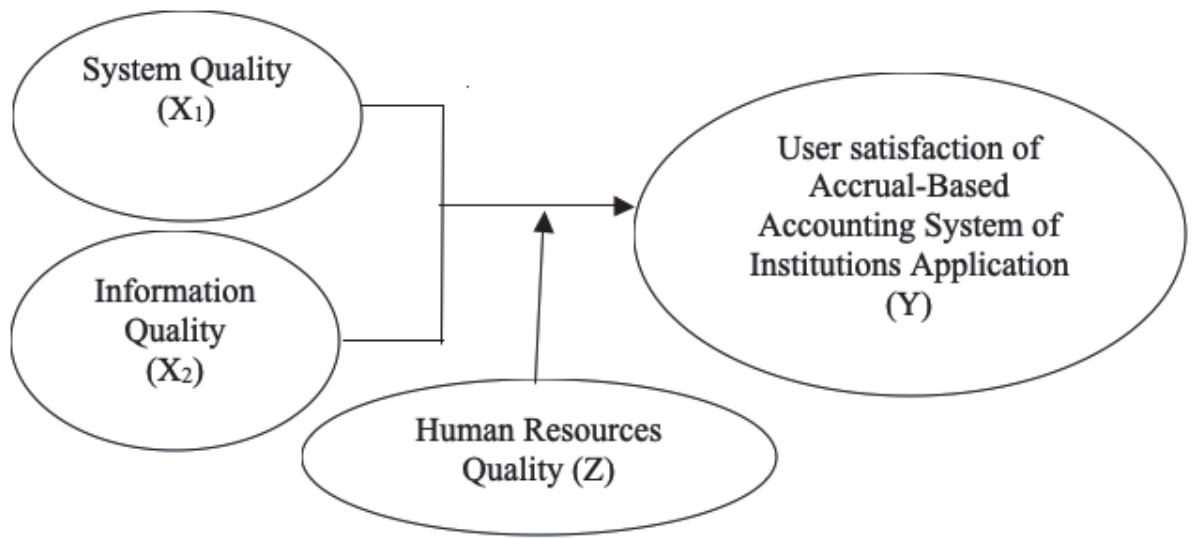

The conceptual framework which will be used can be described as follows: Figure 1. Conceptual Framework

\section{Research method}

This type of research is explanatory research. An explanatory study which is a study that explains the causal relationship between research variables with hypothesis testing. In explanatory research, the approach used in this research is survey method that is research done to obtain facts about phenomena that exist in research object and searching actual and systematic 
information (Lutfi et al., 2016; Yahya et al., 2017; Syahyunan et al., 2017; Tarmizi et al., 2017; Badaruddin et al., 2017; Muda and Nurlina, 2018 and Muda et al., 2018). This research applied survey method with census sampling technique. The population in this research is the operators of Accrual-Based Accounting System of Institutions Application in the service partner work units of Indonesia with the total of 209 work units, where each work unit will be given 1 (one) questionnaire to be filled by the operators. The instrument of this research was a questionnaire designed by the researcher based on the adaptation on the research conducted by Libby (2017); Alalwan et al., (2017); Visinescu et al., (2017); Nasution (2016); Lubis et al., (2016) and Muda et al., (2017). The variables of this research were measured by using the scale of interval measurement, through the questionnaire with a score ranging from 1 to 5 . The operational definitions and measurement scale are briefly described in the following Table:

Table 1. Operational Definitions

\begin{tabular}{|c|c|c|c|}
\hline Variable & Definition of Variable & Variable Measurement & Scale \\
\hline $\begin{array}{l}\text { Dependent Variable } \\
\text { User satisfaction of } \\
\text { Accrual-Based Accounting } \\
\text { System of Institutions } \\
\text { application } \\
\text { (Y) }\end{array}$ & $\begin{array}{l}\text { The response of the users of } \\
\text { application (operators) on } \\
\text { Accrual-Based Accounting } \\
\text { System of Institutions } \\
\text { application and the output } \\
\text { resulted from Accrual- } \\
\text { Based Accounting System of } \\
\text { Institutions application. }\end{array}$ & $\begin{array}{l}\text { Measurement Indicators: } \\
\text { (Nurzaimah et al., 2016; } \\
\text { Woodham et al.,2017; Hussain } \\
\text { et al., 2017; Filieri et al., 2017; } \\
\text { Lin, 2017; Efthymiou and } \\
\text { Antoniou, 2017; Kim et al., } \\
\text { 2017; Radu et al., 2017; Hong } \\
\text { et al. 2017 Berger et al., 2017; } \\
\text { Carrasco et al., 2017; Yousuf } \\
\text { and Wahab, 2017; Laumer } \\
\text { et al., 2017; Kiran and Diljit, } \\
\text { 2017; Balaji et al., 2017; Yang, } \\
\text { 2017; Noutsa et al., 2017; Ryu } \\
\text { and Lee., 2017; Cleverley et } \\
\text { al., 2017 and Kilsdonk et al., } \\
\text { 2017) } \\
\text { Content Comprehensiveness } \\
\text { Accuracy } \\
\text { Appearance } \\
\text { Ease of Use } \\
\text { Pertinence }\end{array}$ & Interval \\
\hline
\end{tabular}




\begin{tabular}{|c|c|c|c|}
\hline Variable & Definition of Variable & Variable Measurement & Scale \\
\hline \multicolumn{4}{|l|}{ Independent Variable } \\
\hline $\begin{array}{l}\text { System Quality } \\
\text { (X1) }\end{array}$ & $\begin{array}{l}\text { The Quality of the used } \\
\text { Accrual-Based Accounting } \\
\text { System of Institutions } \\
\text { application, perceived from the } \\
\text { perception of the users of the } \\
\text { application (operators). }\end{array}$ & $\begin{array}{l}\text { Measurement Indicators: } \\
\text { (Petter,et al., 2013; Abdillah } \\
\text { and Jogiyanto, 2015; Lubis et } \\
\text { al., 2016; } \\
\text { Libby, 2017; Alalwan et al., } \\
\text { 2017; Visinescu et al.,2017; } \\
\text { Hariguana et al., 2017; Wang } \\
\text { and Lin, 2017; Vischer and } \\
\text { Wifi et al., 2017; Visinescu } \\
\text { et al., 2017; McKnight et al., } \\
\text { 2017; Li et al., 2017; Hamari, } \\
\text { et al., 2017; Chen et al., 2017; } \\
\text { Ren et al., 2017; Luo and } \\
\text { Chea, 2017; Uppal et al., 2017 } \\
\text { and Shang et al., 2017) } \\
\text { Flexibility } \\
\text { Security } \\
\text { Correctable } \\
\text { Understandable } \\
\text { Ease of Use }\end{array}$ & Interval \\
\hline $\begin{array}{l}\text { Information Quality } \\
\text { (X2) }\end{array}$ & $\begin{array}{l}\text { The Quality of information } \\
\text { (output) resulted from the used } \\
\text { Accrual-Based Accounting } \\
\text { System of Institutions } \\
\text { application, perceived from the } \\
\text { perception of the users of the } \\
\text { application (operators). }\end{array}$ & $\begin{array}{l}\text { Measurement Indicators: } \\
\text { (Rostaminezhad et al, 2013; } \\
\text { Muda et al., 2016; Diavastisa } \\
\text { et al., 2017; Gorla et al., 2017; } \\
\text { Dooley et al., 2017; Tarí et } \\
\text { al., 2017; Barata and Cunha, } \\
\text { 2017; Liu et al., 2017; Liang } \\
\text { et al., 2017; Sun and Teng, } \\
\text { 2017; Gao et al., 2017; Hsieh } \\
\text { and Lin, 2017; Libby, 2017; } \\
\text { Alalwan et al., 2017; Visinescu } \\
\text { et al.,2017; and Hsu et al., } \\
\text { 2017) } \\
\text { Accurate } \\
\text { Trustable } \\
\text { On time } \\
\text { Relevant } \\
\text { Understandable } \\
\text { Detailed }\end{array}$ & Interval \\
\hline
\end{tabular}


Moderating Variable

Human Resources Quality (Z)
The ability of the operators in performing their tasks in financial management.

The data analysis used in this research was Partial Least Square (PLS)approach. PLS is a component- or variance-based equation model of Structural Equation Modelling (SEM). PLS is an alternative approach that shifts from the Covarian-based to variance-based SEM approach (Ghozali and Latan, 2015). This SEM test used SmartPLS version 3.0 program.

\section{Results and discussion}

\section{Measurement Model (Outer Model)}

The measurement model was used to test the validity of the construct and the reliability of the instrument (Abdillah and Jogiyanto, 2015; Tarmizi et al., 2016 \& Sihombing et al., 2017). The validity test of the construct used two methods, they were convergent validity and discriminant validity, while the reliability test of the construct used composite reliability (Sirojuzilam et al, 2016 \& 2017).

\section{Convergent Validity}

An indicator is said to be valid if it has a loadings factor of more than 0,5 and an average variance extracted ( $A V E$ ) value of more than 0,50 towards the target construct (Muda and Hasibuan, 2018). The AVE values from the result of PLS Algorithm of SmartPLS program can be seen in the following Table 2 : 
Table 2 Average Variance Extracted (AVE) Values

Variable

System Quality (X1)

Information Quality (X2)

Human Resources Quality (Z)

User Satisfaction (Y)

Human Resources Quality*System Quality

Human Resources Quality*Information Quality
Average Variance Extracted (AVE)

Information

Source: Data processed (2017).

The loadings factor and AVE values resulted from PLS Algorithm of SmartPLS program can be seen in the following Table 3 :

Table 3 Loadings Factor Values

\begin{tabular}{|c|c|c|c|c|c|c|}
\hline Variable & Indicator & $\begin{array}{l}\text { Loadings } \\
\text { Factor }\end{array}$ & Information & Indicator & $\begin{array}{l}\text { Loadings } \\
\text { Factor }\end{array}$ & Information \\
\hline \multirow[t]{3}{*}{ System Quality (X1) } & KS1 & \multirow{3}{*}{$\begin{array}{l}0.819 \\
0.893 \\
0.772\end{array}$} & Valid & KS4 & \multirow{3}{*}{$\begin{array}{l}0.810 \\
0.842 \\
0.766\end{array}$} & Valid \\
\hline & KS2 & & Valid & KS5 & & Valid \\
\hline & KS3 & & Valid & KS6 & & Valid \\
\hline \multirow[t]{3}{*}{ Information Quality (X2) } & KI1 & 0.813 & Valid & KI4 & 0.811 & Valid \\
\hline & $\mathrm{KI} 2$ & 0.856 & Valid & KI5 & 0.789 & Valid \\
\hline & $\mathrm{KI} 3$ & 0.757 & Valid & KI6 & 0.818 & Valid \\
\hline \multirow{3}{*}{$\begin{array}{l}\text { Human Resources Quality } \\
\text { (Z) }\end{array}$} & SDM1 & 0.912 & Valid & SDM4 & 0.937 & Valid \\
\hline & SDM2 & 0.907 & Valid & SDM5 & 0.815 & Valid \\
\hline & SDM3 & 0.883 & Valid & & & \\
\hline \multirow[t]{5}{*}{ User Satisfaction (Y) } & KP1 & 0.828 & Valid & KP6 & 0.617 & Valid \\
\hline & KP2 & 0.828 & Valid & KP7 & 0.711 & Valid \\
\hline & KP3 & 0.872 & Valid & KP8 & 0.604 & Valid \\
\hline & KP4 & 0.838 & Valid & KP9 & 0.806 & Valid \\
\hline & KP5 & 0.850 & Valid & KP10 & 0.782 & Valid \\
\hline
\end{tabular}


I. Muda \& A. A. Erlina / Contaduría y Administración 64(2), 2019 1-25 http://dx.doi.org/10.22201/fca.24488410e.2019.1667

\begin{tabular}{|c|c|c|c|c|c|c|}
\hline \multirow{15}{*}{$\begin{array}{l}\text { Human Resources } \\
\text { Quality*System Quality }\end{array}$} & SDM1 $*$ KS1 & 0.564 & Valid & SDM3 $*$ KS4 & 0.550 & Valid \\
\hline & $\mathrm{SDM} 1 * \mathrm{KS} 2$ & 0.654 & Valid & SDM3 $*$ KS5 & 0.600 & Valid \\
\hline & $\mathrm{SDM} 1 * \mathrm{KS} 3$ & 0.532 & Valid & $\mathrm{SDM} 3 *$ KS6 & 0.598 & Valid \\
\hline & $\mathrm{SDM} 1 * \mathrm{KS} 4$ & 0.533 & Valid & $\mathrm{SDM} 4 * \mathrm{KS} 1$ & 0.584 & Valid \\
\hline & SDM1 1 KS5 & 0.543 & Valid & $\mathrm{SDM} 4 * \mathrm{KS} 2$ & 0.679 & Valid \\
\hline & SDM1 * KS6 & 0.588 & Valid & $\mathrm{SDM} 4 * \mathrm{KS} 3$ & 0.573 & Valid \\
\hline & $\mathrm{SDM} 2 * \mathrm{KS} 1$ & 0.558 & Valid & $\mathrm{SDM} 4 * \mathrm{KS} 4$ & 0.547 & Valid \\
\hline & $\mathrm{SDM} 2 * \mathrm{KS} 2$ & 0.652 & Valid & SDM4 $*$ KS5 & 0.580 & Valid \\
\hline & $\mathrm{SDM} 2 * \mathrm{KS} 3$ & 0.568 & Valid & SDM $4 *$ KS6 & 0.611 & Valid \\
\hline & $\mathrm{SDM} 2 * \mathrm{KS} 4$ & 0.528 & Valid & SDM5 * KS1 & 0.524 & Valid \\
\hline & SDM2 $*$ KS5 & 0.547 & Valid & SDM5 * KS2 & 0.587 & Valid \\
\hline & $\mathrm{SDM} 2 * \mathrm{KS} 6$ & 0.573 & Valid & $\mathrm{SDM} 5 * \mathrm{KS} 3$ & 0.511 & Valid \\
\hline & $\mathrm{SDM} 3 * \mathrm{KS} 1$ & 0.551 & Valid & SDM5 $*$ KS4 & 0.522 & Valid \\
\hline & $\mathrm{SDM} 3 * \mathrm{KS} 2$ & 0.632 & Valid & SDM5 * KS5 & 0.554 & Valid \\
\hline & $\mathrm{SDM} 3 * \mathrm{KS} 3$ & 0.553 & Valid & SDM5 * KS6 & 0.551 & Valid \\
\hline \multirow{15}{*}{$\begin{array}{l}\text { Human Resources } \\
\text { Quality*Information } \\
\text { Quality }\end{array}$} & SDM1 * KI1 & 0.615 & Valid & SDM3 $*$ KI4 & 0.565 & Valid \\
\hline & $\mathrm{SDM} 1 * \mathrm{KI} 2$ & 0.647 & Valid & $\mathrm{SDM} 3 * \mathrm{KI} 5$ & 0.615 & Valid \\
\hline & $\mathrm{SDM} 1 * \mathrm{KI} 3$ & 0.582 & Valid & SDM3 * KI6 & 0.608 & Valid \\
\hline & SDM1 * KI4 & 0.608 & Valid & SDM4 * KI1 & 0.633 & Valid \\
\hline & SDM1 $*$ KI5 & 0.678 & Valid & SDM4 * KI2 & 0.657 & Valid \\
\hline & SDM1 * KI6 & 0.630 & Valid & $\mathrm{SDM} 4 * \mathrm{KI} 3$ & 0.577 & Valid \\
\hline & SDM2 $*$ KI1 & 0.650 & Valid & SDM4 * KI4 & 0.616 & Valid \\
\hline & $\mathrm{SDM} 2 * \mathrm{KI} 2$ & 0.668 & Valid & SDM4 $*$ KI5 & 0.665 & Valid \\
\hline & $\mathrm{SDM} 2 * \mathrm{KI} 3$ & 0.656 & Valid & SDM4 * KI6 & 0.645 & Valid \\
\hline & $\mathrm{SDM} 2 * \mathrm{KI} 4$ & 0.615 & Valid & SDM5 * KI1 & 0.596 & Valid \\
\hline & $\mathrm{SDM} 2 * \mathrm{KI} 5$ & 0.679 & Valid & SDM5 * KI2 & 0.540 & Valid \\
\hline & SDM2 * KI6 & 0.636 & Valid & SDM5 * KI3 & 0.547 & Valid \\
\hline & SDM3 * KI1 & 0.630 & Valid & SDM5 * KI4 & 0.521 & Valid \\
\hline & $\mathrm{SDM} 3 * \mathrm{KI} 2$ & 0.639 & Valid & SDM5 * KI5 & 0.523 & Valid \\
\hline & SDM3 $*$ KI3 & 0.544 & Valid & SDM5 * KI6 & 0.594 & Valid \\
\hline
\end{tabular}




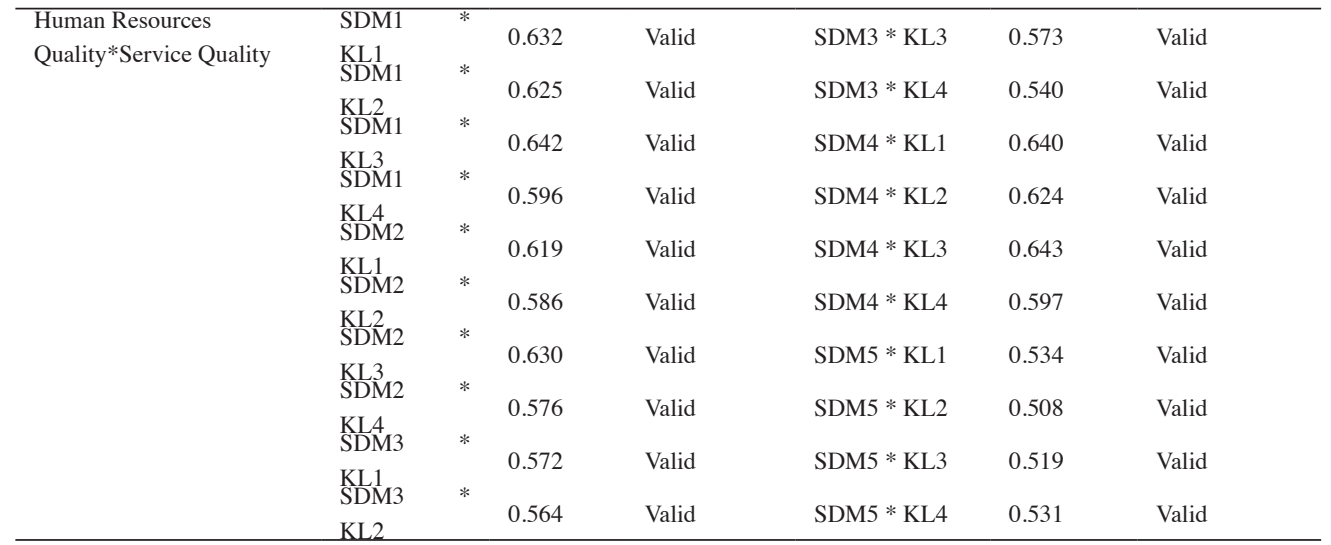

Source: Data processed (2017).

\section{Discriminant Validity}

If the square root value of AVE of each construct is greater than the correlation value between a construct and another construct in the model, it can be said that it has a good discriminant validity value (Fornnel and Larcker, 1981 in Ghozali and Latan, 2015). The square root values of AVE resulted from the PLS Algorithm of SmartPLS program can be seen in the following Table 4:

Table 4 Square Root Values of AVE

\begin{tabular}{|c|c|c|c|c|c|c|}
\hline Variable & $\begin{array}{l}\text { Information } \\
\text { Quality (X2) }\end{array}$ & $\begin{array}{l}\text { User } \\
\text { Satisfaction } \\
\text { (Y) }\end{array}$ & $\begin{array}{l}\text { System } \\
\text { Quality } \\
\text { (X1) }\end{array}$ & $\begin{array}{l}\text { Human } \\
\text { Resources } \\
\text { Quality (Z) }\end{array}$ & $\begin{array}{l}\text { Human } \\
\text { Resources } \\
\text { Quality } \\
* \text { System } \\
\text { Quality }\end{array}$ & $\begin{array}{l}\text { Human } \\
\text { Resources } \\
\text { Quality* } \\
\text { Information } \\
\text { Quality }\end{array}$ \\
\hline $\begin{array}{l}\text { Information Quality } \\
\text { (X2) }\end{array}$ & 0.808 & & & & & \\
\hline User Satisfaction (Y) & 0.497 & 0.779 & & & & \\
\hline System Quality (X1) & 0.369 & 0.537 & 0.818 & & & \\
\hline $\begin{array}{l}\text { Human Resources } \\
\text { Quality (Z) } \\
\text { Human Resources }\end{array}$ & 0.223 & 0.441 & 0.218 & 0.892 & & \\
\hline $\begin{array}{l}\text { Quality * System } \\
\text { Quality } \\
\text { Human Resources }\end{array}$ & 0.016 & 0.391 & 0.100 & -0.036 & 0.765 & \\
\hline $\begin{array}{l}\text { Quality * Information } \\
\text { Quality }\end{array}$ & -0.179 & 0.330 & 0.005 & 0.050 & 0.480 & 0.791 \\
\hline
\end{tabular}

Source: Data processed (2017). 


\section{Composite Reliability}

Ghozali and Latan (2015) stated that a latent variable has a high reliability if it has a composite reliability value of more than 0.60 . The composite reliability values resulted from the PLS Algorithm of SmartPLS program can be seen in the following Table 5:

Table 5 Composite Reliability Values

\begin{tabular}{lll}
\hline Variable & Composite Reliability & Information \\
\hline System Quality (X1) & 0.924 & Reliable \\
Information Quality (X2) & 0.918 & Reliable \\
Human Resources Quality (Z) & 0.951 & Reliable \\
User Satisfaction (Y) & 0.938 & Reliable \\
Human Resources Quality * System Quality & 0.977 & Reliable \\
Human Resources Quality * Information Quality & 0.980 & Reliable \\
\hline
\end{tabular}

Source: Data processed (2017).

\section{$R$-square}

The higher the $\mathrm{R}^{2}$ value, the better the prediction model of the proposed research model. A strong model is shown by the value of 0.67 , a moderate model is shown by the value of 0.33 and a weak model is shown by the value of 0.19 (Chin, 1998 in Ghozali and Latan, 2015; Handoko et al., 2017; Situmorang et al., 2017; Sadalia et al., 2017 and Erlina and Muda, 2018). The $\mathrm{R}^{2}$ value is used to explain the effect of the latent (independent) variable on the latent (dependent) variable or how great the effect is. The $R$-square value resulted from $P L S$ Algorithm of SmartPLS program can be seen in the following Table 6 :

Table 6 R-Square Value

\begin{tabular}{ll}
\hline Variable & R-Square \\
\hline User Satisfaction without Moderating Effect & 0.482 \\
User Satisfaction with Moderating Effect & 0.655 \\
\hline
\end{tabular}

Source: Data processed (2017).

\section{Hypothesis test}

The hypothesis test used the significance level of 5\% and confidence level of $95 \%$. In order to make a hypothesis accepted (Syahyunan, et al., 2017; Nurlina et al., 2017; Ferine et al., 2017; Sari et al., 2018; Sadalia et al., 2018; Erlina and Muda, 2018 and Erwin et al., 2018) 
it has to have a t-statistics value $>1,96$. Table 7 shows the results of path coefficients and t-statistics.

Table 7 The Path Coefficients and $t$ Statistics Values

\begin{tabular}{|c|c|c|c|c|c|c|c|}
\hline & $\begin{array}{l}\text { Original } \\
\text { Sample } \\
\text { (O) }\end{array}$ & $\begin{array}{l}\text { Sample } \\
\text { (M) }\end{array}$ & Mean & $\begin{array}{l}\text { Standard } \\
\text { Deviation } \\
\text { (STDEV) }\end{array}$ & $\begin{array}{ll}\text { T } & \text { Statistics } \\
(\mathrm{IO} / \mathrm{STDEVI})\end{array}$ & $\mathrm{p}$ Values & Information \\
\hline $\mathrm{KI}$-> KP & 0.360 & 0.363 & & 0.090 & 3.983 & 0.000 & $\begin{array}{l}\text { Hypothesis } \\
\text { is accepted } \\
(\mathrm{p}<0.05)\end{array}$ \\
\hline $\mathrm{KS}->\mathrm{KP}$ & 0.316 & 0.314 & & 0.073 & 4.362 & 0.000 & $\begin{array}{l}\text { Hypothesis } \\
\text { is accepted } \\
(\mathrm{p}<0.05)\end{array}$ \\
\hline KSDM -> KP & 0.287 & 0.291 & & 0.084 & 3.431 & 0.001 & $\begin{array}{l}\text { Hypothesis } \\
\text { is accepted } \\
(\mathrm{p}<0.05)\end{array}$ \\
\hline Moderating Effect $1->\mathrm{KP}$ & 0.316 & 0.303 & & 0.127 & 2.496 & 0.013 & $\begin{array}{l}\text { Hypothesis } \\
\text { is accepted } \\
(\mathrm{p}<0.05)\end{array}$ \\
\hline Moderating Effect $2->$ KP & 0.342 & 0.371 & & 0.143 & 2.395 & 0.017 & $\begin{array}{l}\text { Hypothesis } \\
\text { is accepted } \\
(\mathrm{p}<0.05)\end{array}$ \\
\hline
\end{tabular}

Source: Data processed (2017).

\section{Discussion}

Based on the results of the test in Table 7, the effect of each variable is described as follows:

The effect of system quality on user satisfaction

The system quality variable $\left(\mathrm{X}_{1}\right)$ has a $t$-statistics value of 4,362 which is greater than 1,96 and a positive path coefficient value, thus, hypothesis 1 is accepted. It can be concluded that the system quality variable has a significant positive effect on the user satisfaction of Accrual-Based Accounting System of Institutions application. The results of this study support the success model of information system proposed by DeLone \& McLean (2003), Seddon and Kiew (1996), Iivari (2005), Petter,et al., (2013); Abdillah and Jogiyanto, (2015); Lubis et al., (2016); Libby (2017); Alalwan et al., (2017); Visinescu et al., (2017); Hariguana et al., (2017); Wang and Lin, (2017); Vischer and Wifi et al., (2017); McKnight et al., (2017); Li et al., (2017); Hamari, et al., (2017); Chen et al., (2017); Ren et al., (2017); Luo and Chea, (2017); Uppal et al., (2017) and Shang et al., (2017). Security is very important to prevent the misuse or changes of the data for personal purposes. In order to be able to access this application, the username and password are used for security purposes. It is more on the fulfillment of the needs of the institutions since this application adopts the business processes of the activities of the institutions, so that the features of this application are suited to the needs of the users. 
The effect of information quality on user satisfaction

The information quality variable $\left(\mathrm{X}_{2}\right)$ has a T-statistics value of 3.983 which is greater than 1.96 and a positive path coefficient value, thus, hypothesis 2 is accepted. It can be concluded that the information quality variable has a significant positive effect on user satisfaction of Accrual-Based Accounting System of Institutions application. The results of this study support the success model of information system proposed by DeLone \& McLean (2003), Seddon and Kiew (1996), Livari (2005), Rostaminezhad et al, 2013; Muda et al., 2016; Libby (2017); Alalwan et al., (2017); Visinescu et al., (2017); Muda et al., (2017), Diavastisa et al., (2017); Gorla et al., (2017); Dooley et al., (2017); Tarí et al., 2017; Barata and Cunha, 2017; Liu et al., 2017; Liang et al., 2017; Sun and Teng, (2017); Gao et al., (2017); Hsieh and Lin, (2017) and Hsu et al., (2017). The Accrual-Based Accounting System of Institutions application makes the recording and reporting processes which previously took a longer time to be faster and easier. It makes the information resulted from the application is useful for consideration in making decisions as it is available when needed.

\section{The effect of human resources quality on user satisfaction}

The human resources quality variable $\left(\mathrm{X}_{4}\right)$ has a T-statistics value of 3.431 which is greater than 1.96 and a positive path coefficient, thus, hypothesis 4 is accepted. It can be concluded that the human resources quality variable has a positive significant effect on the user satisfaction of Accrual-Based Accounting System of Institutions application. The results of this study are in line with the results of the research conducted by Mendoza et al., 2011; Cheuk et al., 2017; Iannacci and Comford, 2017; Zerbino et al. 2017; Tam et al., 2017; Hernandez-Ortega et al., 2017; Sánchez et al., 2017; Almazán et al., 2017; Alzahrani, et al., 2017; Shin et al., 2017; Horvath and Bauermeister, 2017 and Hsu et al., 2017. The operator of work unit is the most associated party with the operations of Accrual-Based Accounting System of Institutions application. Human resources as the users of application have a direct connection with the implementation of the system. Therefore, the competence of the users of application is a very important factor in the successful implementation of Accounting Information System (SIA).

Human resources quality moderates the relationship between system quality and user satisfaction

The Human Resources quality variable system quality has a T-statistics value of 2.496 which is greater than 1.96 and a positive path coefficient value, thus, hypothesis 5 is accepted. It can be concluded that human resources quality can mderate the relationship between the system quality and user satisfaction of Accrual-Based Accounting System of Institutions application. The research conducted by Mendoza et al., 2011; Cheuk et al., 2017; Iannacci and Comford, 2017; Zerbino et al. 2017; Tam et al., 2017; Hernandez-Ortega et al., 2017; Sánchez et al., 2017; Almazán et al., 2017; Alzahrani, et al., 2017; Shin et al., 2017; Horvath and Bauermeister, 2017 and Hsu et al., 2017 stated that the participation of information system users is expected to improve the quality of information system, because an information system will 
not be effective in assisting the work if it does not involve the users of accounting information system. The users of accounting information system who obtain ability from a training program or education and experience can increase their satisfaction in the use of the applied accounting information system.

Human resources quality moderates the relationship between information quality and user satisfaction

The human resources quality information quality has a T-statistics value of 2.395 which is greater than 1.96 and a positive path coefficient, thus, hypothesis 6 is accepted. It can be concluded that human resources quality can moderate the relationship between the information quality and user satisfaction of Accrual-Based Accounting System of Institutions application. The qualified human resources will be able to carry out the accounting information system by understanding and applying the logic of accounting well according to the prevailing regulations. The human resources of the Government who fail to understand and apply the logic of accounting will have an impact on the mistakes in making financial statements and mismatch reports with the standards set by the government (Jung, 2017; Sforza and Cimini, 2017; Muda et al., 2017, Agasisti et al.,2017; Fuchs et al., 2017; Cohen et al., 2017 and Caperchione et al., 2017). The Accrual-Based Accounting System of Institutions application is a financial system that is stored online with the goal of transparency for each party. This system is applied as an accrual based budgeting documentation. Everyone can access the budget data compiled by a local government so that it is expected to prevent the embezzlement of funds or fraud from the local bureaucracy (Yahya et al., 2017). Monitoring financial data as well as its control by the public is a practice of financial democratization in a local government. Citizens can immediately issue a complaint if they suspect undue data. They can also ascertain whether the paid tax funds are being used properly. Public transparency is an obligation of every local government to prevent and anticipate all fraudulent acts in the management of state finances. The thing that is considered in the organization is the morale of each employee. The spirit of employees is important because it can increase productivity. Employees who have low morale tend to generate financial costs in the organization, while employees who have a high morale tend to generate financial benefits within the organization.

\section{Conclusions}

The conclusions of this study are as follows:

System quality has a significant positive effect on the user satisfaction of Accrual-Based Accounting System of Institutions application in the service partner work units of Indonesia Government. The higher the value of system quality the higher the level of user satisfaction of the Accrual-Based Accounting System of Institutions application. The level of satisfaction includes content satisfaction, accuracy, appearance, ease of use and pertinence. These results support the Adaptive Behavior Assessment System (ABAS) Theory in which behavioral analysis experiments find a large number of principles of statements about how content satisfaction, 
accuracy, appearance, ease of use and pertinence as a function of environmental variables. The tactics for changing behavior are derived from principles that have also been applied, in a more effective and sophisticated way, for most human behavior in a variety of natural settings. Humans are created to be able to learn with a range of extraordinary behavior. The series of responses, sometimes seemingly not included in the organization of logic, supports the complexity of human behavior. The System quality and information quality together affect to the user satisfaction. The amount of use can affect user satisfaction positively. The user satisfaction affect on individual impact and then affect to the organizational impact. Information systems have a role in supporting operational business activities, supporting management in decision making, and supporting the advantages of an organization's competitive strategy. Information systems can be used to create strategic advantages. Strategic excellence is an advantage that has a fundamental impact in shaping the organization's operations.

Information quality has a significant positive effect on the user satisfaction of Accrual-Based Accounting System of Institutions application in the service partner work units of Indonesia Government. The higher the acceptance levels the more accurate, trustable, on time, relevant, understandable and detailed. These results support the Adaptive Behavior Assessment System (ABAS) Theory in which Information quality generated from the Information system in the modern business competition climate plays a very important role so as to be able to create, manipulate and capture information problems that develop both internally and externally. The effectiveness of information systems will be useful for management of a business entity to make changes to business development strategies. The use of an information system is expected to provide competitive advantage and comparative advantage for the company. Implementation of effective and efficient information technology is expected to be a success factor for a business entity.

Human Resources quality has a significant positive effect on the user satisfaction of Accrual-Based Accounting System of Institutions application in the service partner work units of Indonesia Government. The better the educational background, experience, the amount of training and know the ins and outs of accounting and professional in their field, the better the application of Accrual-Based Accounting System. Changes from manual systems to computerized systems not only involve changes in technology but also changes in behavior and organization. Therefore, the main impact of information technology is mediated by a number of factors, many of which require an in-depth understanding of the organizational context and human behavior. These results support the Adaptive Behavior Assessment System (ABAS) Theory where Human Resources quality supports the development of Information Technology. Human Resources quality has an effect on the user satisfaction of Accrual-Based Accounting System of Institutions application on the ease and smoothness of information or data processing. Human Resources quality supports the information technology function as retrieving, collecting, processing, storing, distributing, and presenting information will facilitate the Personnel Management process to manage its human resources well and quickly, of course by minimizing possible human errors. This is what makes these two aspects mutually connected and synchronized.

Human Resources quality can moderate the relationship between the system quality and user satisfaction of Accrual-Based Accounting System of Institutions application in the service partner work units of Indonesia Government. The Human Resources function serves as the moderating variable of the relationship between System Quality and the Flexibility, Security, 
Correctable, Understandable and Ease of Use indicators of the user satisfaction of the AccrualBased Accounting System of Institutions application. These results support the Adaptive Behavior Assessment System (ABAS) Theory where Human Resources quality supports moderated the relationship between the system quality and user satisfaction of Accrual-Based Accounting System of Institutions application. Organizations are required to be more responsive to users and can improve the quality of users. Service quality and user satisfaction are important because the user's trust in the quality of the system is a construct that determines the possibility of a repeat purchase from the user and ultimately affects the success of an organization. User satisfaction is one of the factors to measure success for every development and implementation of information application systems in an organization. A good quality service image is not based on the perspective or perception of the service provider, but based on the user's perception.

Human Resources quality can moderate the relationship between the information quality and user satisfaction of Accrual-Based Accounting System of Institutions application in the service partner work units of Indonesia Government. The Human Resources function serves as the moderating variable of the relationship between Information Quality and Accurate, accurate, trustable, on time, relevant, understandable and detailed indicators of user satisfaction of the Accrual-Based Accounting System of Institutions application. These results support the Adaptive Behavior Assessment System (ABAS) Theory where Human Resources quality supports moderate the relationship between the information quality and user satisfaction of Accrual-Based Accounting System. Technological development is very rapid, information technology created is increasingly sophisticated, so employees must have broad capabilities and skills. However, not all employees have broad skills and skills so training and human resource development are needed so that their abilities and skills can be used in carrying out organizational activities. A well-organized Human Resource Information System, organizations can get any information related to employees. Management of human resource management is all programs ranging from human resource planning, recruitment, employee development, career development to pension programs can be implemented optimally and on target. Human Resources Information Systems must be designed to provide information. The desired information generally includes timely, accurate, concise, relevant, complete. An effective personnel information system is very helpful for decision making for organizational leaders in good human resource management.

The results of the study can contribute to the knowledge and development of accounting literature, especially public sector accounting, which is related to the interaction of the financial report compilers using applications at the lowest level of the accounting entity. Simultaneously the results of this study are expected to contribute to the government in this case the Ministry of Finance can be feedback, input and can be a reference in making future policies, especially those relating to the development of accounting systems applications that involve many stakeholders. 


\section{References}

Abdullah, W., \& Jogiyanto. (2015). Partial Least Square (PLS). Yogyakarta: Andi Publisher.

Achmad, N; \& Muda, I. (2017). Economic Activities of Karo Older Adults in Lingga Village, Tanah Karo Regency, North Sumatera, Indonesia. International Journal of Economic Research. 14(16). 365-379.

Agasisti, T., Catalano, G., \& Erbacci, A. (2017). How Resistance to Change Affects the Implementation of Accrual Accounting in Italian Public Universities: A Comparative Case Study. International Journal of Public Administration, 1-11.

Alalwan, A. A., Dwivedi, Y. K., \& Rana, N. P. (2017). Factors influencing adoption of mobile banking by Jordanian bank customers: Extending UTAUT2 with trust. International Journal of Information Management, 37(3), 99-110.

Almazán, Demian Abrego, Yesenia Sánchez Tovar, José Medina Quintero. (2017). Influence of information systems in organizational performance. Contaduría y Administración. 62(2). 321-338.

Alzahrani, L., Al-Karaghouli, W., \& Weerakkody, V. (2017). Analysing the critical factors influencing trust in e-government adoption from citizens' perspective: A systematic review and a conceptual framework. International Business Review, 26(1). 164-175.

American Association on Mental Deficiency/AAMD, (1983). Classification I In Mental Retardation. American Association on Mental Deficiency 1719 Kalorama Road, NW Washington, DC.

Badaruddin; Revida, E; Ermansyah \& Muda, I. (2017). Village Governance With Implementation of Law Number 6 of 2014 On The Village and Village Administration. International Journal of Economic Research. 14(16). 350-363.

Balaji, M. S., Roy, S. K., \& Lassar, W. M. (2017). Language divergence in service encounters: Revisiting its influence on word-of-mouth. Journal of Business Research, 72, 210-213.

Barata, J., \& Cunha, P. R. (2017). Synergies between quality management and information systems: a literature review and map for further research. Total Quality Management \& Business Excellence, 28(3-4). 282-295.

Berger, B., Geimer, A., \& Hess, T. (2017). Will They Stay or Will They Go? An Examination of the Factors Influencing User Loyalty towards News Websites. In Proceedings of the 50th Hawaii International Conference on System Sciences.

Caperchione, E., Demirag, I., \& Grossi, G. (2017). Public sector reforms and public private partnerships: Overview and research agenda. Accounting Forum. 41(1). 1-7.

Carrasco, R. A., Sánchez-Fernández, J., Muñoz-Leiva, F., Blasco, M. F., \& Herrera-Viedma, E. (2017). Evaluation of the hotels e-services quality under the user's experience. Soft Computing, 21(4), 995-1011.

Chen, X., Huang, Q., \& Davison, R. M. (2017). The role of website quality and social capital in building buyers' loyalty. International Journal of Information Management, 37(1), 1563-1574.

Cheuk, K. P., Baskarada, S., \& Koronios, A. (2017). Contextual factors in knowledge reuse. VINE Journal of Information and Knowledge Management Systems, 47(2). 88-98.

Cleverley, P. H., Burnett, S., \& Muir, L. (2017). Exploratory information searching in the enterprise: A study of user satisfaction and task performance. Journal of the Association for Information Science and Technology, 68(1). 77-96.

Cohen, S., Cohen, S., Karatzimas, S., \& Karatzimas, S. (2017). Accounting information quality and decision-usefulness of governmental financial reporting: Moving from cash to modified cash. Meditari Accountancy Research, 25(1). 95-113.

Dalimunthe, D.M.J., and Muda, I. (2017). The Empirical Effect of Education and Training to The Performance of Employees. International Journal of Applied Business and Economic Research. 15(24). 5423-5437.

Dalimunthe, D.M.J.,Fadli, and Muda, I. (2016). The application of performance measurement system model using Malcolm Baldrige Model (MBM) to support Civil State Apparatus Law (ASN) number 5 of 2014 in Indonesia. International Journal of Applied Business and Economic Research. 14(11). 7397-7407.

DeLone, W. H., \& McLean, E. R. (1992). Information systems success: The quest for the dependent variable. Information systems research. 3(1). 60-95.

DeLone, W. H., \& Mclean, E. R. (1992). The DeLone McLean Model Of Success System Information: A ten-Year Update. Journal of Management Information, 19(4). 9-30.

DeLone, W. H., \& McLean, E.R. (2003). The DeLone and McLean Model of Information System Success: A Ten Year Update. Journal of Management Information Systems, 19(1). 9-30. 
Diavastisa, I., Anagnostopouloua, E., Drogalasa, G., \& Karagiorgosa, T. (2016). The interaction effect of accounting information systems user satisfaction and Activity-Based Costing use on hotel financial performance: Evidence from Greece. interaction, 15(4). 757-784.

Dooley, P. P., Levy, Y., Hackney, R. A., \& Parrish, J. L. (2018). Critical value factors in business intelligence systems implementations. In Analytics and Data Science. 14(2). 55-78.

Efthymiou, D., \& Antoniou, C. (2017). Understanding the effects of economic crisis on public transport users' satisfaction and demand. Transport Policy, 53, 89-97.

Eriadi, Muda, I, and S.Abdullah, (2018). Determinant Analysis of the Quality of Local Government Financial Statements in North Sumatra with the Effectiveness of Management of Regional Property as a Mediator, International Journal of Civil Engineering and Technology, 9(5). 1334-1346.

Erlina and Muda, I, (2018). Determinants of The Implementation Of Risk-Based Internal Auditing In Regencies/Cities In North Sumatera Province, International Journal of Civil Engineering and Technology, 9(5). 1360 - 1372.

Erlina and Muda, I, (2018). The Effect of Self Efficacy and Professional Development on the Work Quality of Internal Auditor, International Journal of Civil Engineering and Technology, 9(5). 1292-1304.

Erlina, A.ri Saputra \& Muda, I. (2017). Antecedents of Budget Quality Empirical Evidence from Provincial Government In Indonesia. International Journal of Economic Research. 14(12). 301-312.

Erlina. A.Saputra \& Muda, I. (2017). The Analysis of the Influencing Factors of Budget Absorption. International Journal of Economic Research. 14(12). 287-300.

Erwin, K., Abubakar, E., Muda, I. (2018). The relationship of lending, funding, capital, human resource, asset liability management to non-financial sustainability of rural banks (BPRs) in Indonesia. Journal of Applied Economic Sciences, Volume XIII, Spring 2(56): 520 - 542.

Ferine, Kiki Farida; Ermiaty, C. \& Muda, I. (2017). The Impact of Entrepreneurship and Competence On Small Medium Enterprises Tangan Di Atas (TDA) Medan Entrepreneurs' Work Performance. International Journal of Economic Research. 14(16). 380-393.

Filieri, R., McLeay, F., \& Tsui, B. (2017). Antecedents of travellers' satisfaction and purchase intention from social commerce websites. In Information and Communication Technologies in Tourism. 517-528.

Fuchs, S., Bergmann, A., \& Brusca, I. (2017). Using Financial Reporting for Decision Making as a Measure Towards Resilient Government Finances: The Case of Switzerland. Lex Localis, 15(1), 133.

Gao, L., Bai, X., \& Park, A. (2017). Understanding sustained participation in virtual travel communities from the perspectives of IS success model and flow theory. Journal of Hospitality \& Tourism Research, 41(4). 475-509.

Ghozali, I., \& Latan, H. (2015). Partial Least Square, SmartPLS 3.0 (Issue 2). Semarang: Diponegoro University Publishing Agency.

Gorla, N., Somers, T. M., \& Wong, B. (2010). Organizational impact of system quality, information quality, and service quality. The Journal of Strategic Information Systems, 19(3). 207-228.

Government Regulation Number 71 Year 2010 concerning Government Accounting Standards. Jakarta. Republic of Indonesia.

Gresham, F. M., \& Elliott, S. N. (1987). The relationship between adaptive behavior and social skills: Issues in definition and assessment. The Journal of special education, 21(1), 167-181.

Gusnardi, Riadi, R.M., and Muda, I. (2016). Competency mapping and analysis of students competency based on economics subject national examination and its alternative solutions in state high schools at Pekanbaru. International Journal of Economic Research. 3(5). 2133-2148.

Hamari, J., Hanner, N., \& Koivisto, J. (2017). Service quality explains why people use freemium services but not if they go premium: An empirical study in free-to-play games. International Journal of Information Management, 37(1). 1449-1459.

Handoko, B. Sunaryo \& Muda, I. (2017). Difference Analysis of Consumer Perception of Motorcycle Product Quality. International Journal of Economic Research. 14(12). 363-379.

Hernandez-Ortega, B., Hernandez-Ortega, B., Aldas-Manzano, J., Aldas-Manzano, J., Ruiz-Mafe, C., Ruiz-Mafe, C.\& Sanz-Blas, S. (2017). Perceived value of advanced mobile messaging services: A cross-cultural comparison of Greek and Spanish users. Information Technology \& People, 30(2). 324-355. 
Hong, J. C., Tai, K. H., Hwang, M. Y., Kuo, Y. C., \& Chen, J. S. (2017). Internet cognitive failure relevant to users' satisfaction with content and interface design to reflect continuance intention to use a government e-learning system. Computers in Human Behavior, 66, 353-362.

Horvath, K. J., \& Bauermeister, J. A. (2017). eHealth Literacy and Intervention Tailoring Impacts the Acceptability of a HIV/STI Testing Intervention and Sexual Decision Making Among Young Gay and Bisexual Men. AIDS Education and Prevention, 29(1). 14-23.

Hsieh, P. J., \& Lin, W. S. (2017). Explaining resistance to system usage in the PharmaCloud: A view of the dual-factor model. Information \& Management.

Hsu, C. L., Chang, K. C., Kuo, N. T., \& Cheng, Y. S. (2017). The mediating effect of flow experience on social shopping behavior. Information Development, 33(3). 243-256.

Hsu, C. L., Chen, M. C., Kikuchi, K., \& Machida, I. (2017). Elucidating the determinants of purchase intention toward social shopping sites: A comparative study of Taiwan and Japan. Telematics and Informatics, 34(4). 326-338.

Hussain, S., Ahmed, W., Jafar, R. M. S., Rabnawaz, A., \& Jianzhou, Y. (2017). eWOM source credibility, perceived risk and food product customer's information adoption. Computers in Human Behavior, 66. 96-102.

Iannacci, F., \& Cornford, T. (2017). Unravelling causal and temporal influences underpinning monitoring systems success: A typological approach. Information Systems Journal. 12(2). 167-179.

Iivari, J. (2005). An Empirical Test of the DeLone-McLean Model of Information System. The Database for Advances in Infromation System, 36(2). 8-27.

James, J. Q., Hill, D. J., Lam, A. Y., Gu, J., \& Li, V. O. (2018). Intelligent time-adaptive transient stability assessment system. IEEE Transactions on Power Systems, 33(1), 1049-1058.

Jung, C. (2017). Public 6 finance and financial management. Public Administration and Policy in Korea: Its Evolution and Challenges, 118.

Karanasios, S. (2018). Toward a unified view of technology and activity: The contribution of activity theory to information systems research. Information Technology \& People, 31(1), 134-155.

Kilsdonk, E., Peute, L. W., \& Jaspers, M. W. (2017). Factors influencing implementation success of guideline-based clinical decision support systems: A systematic review and gaps analysis. International journal of medical informatics, 98. 56-64.

Kim, S. L., Teo, T. S., Bhattacherjee, A., \& Nam, K. (2017). IS auditor characteristics, audit process variables, and IS audit satisfaction: An empirical study in South Korea. Information Systems Frontiers, 19(3). 577-591.

Kiran, K., \& Diljit, S. (2017). Antecedents of customer loyalty: Does service quality suffice?. Malaysian Journal of Library \& Information Science, 16(2). 95-113.

Krichmar, J. L. (2008). The neuromodulatory system: a framework for survival and adaptive behavior in a challenging world. Adaptive Behavior, 16(6), 385-399.

Laumer, S., Maier, C., \& Weitzel, T. (2017). Information quality, user satisfaction, and the manifestation of workarounds: a qualitative and quantitative study of enterprise content management system users. European Journal of Information Systems, 1-28.

Li, L., Peng, M., Jiang, N., \& Law, R. (2017). An empirical study on the influence of economy hotel website quality on online booking intentions. International Journal of Hospitality Management, 63. 1-10.

Liang, C., Gu, D., Tao, F., Jain, H. K., Zhao, Y., \& Ding, B. (2017). Influence of mechanism of patient-accessible hospital information system implementation on doctor-patient relationships: A service fairness perspective. Information \& Management, 54(1). 57-72.

Libby, R. (2017). Accounting and human information processing. In The Routledge Companion to Behavioural Accounting Research (pp. 42-54). Routledge.

Lin, H. C. (2017). Nurses' satisfaction with using nursing information systems from technology acceptance model and information systems success model perspectives: a reductionist approach. CIN: Computers, Informatics, Nursing, 35(2), 91-99.

Liu, Y., Li, Y., Zhang, H., \& Huang, W. W. (2017). Gender differences in information quality of virtual communities: a study from an expectation-perception perspective. Personality and individual differences, 104. 224-229.

Lubis, A., Rustam and Muda, I. (2016). Factors Affecting The Cost of Agency of Village Owned Enterprise (BUMDES) in Indonesia. International Journal of Economic Research. 14(16). 334-348. 
Lubis, A.,Torong, Z.B., and Muda, I. (2016). The urgency of implementing balanced scorecard system on local government in North Sumatra - Indonesia. International Journal of Applied Business and Economic Research. 14(11). 7575-7590.

Lubis, A.F., Lubis, T.A., and Muda, I. (2016). The role of Enterprise Resource Plan (ERP) configuration to the timeliness of the financial statement presentation. International Journal of Applied Business and Economic Research. 14(11). 7591-7608.

Luo, M. M., \& Chea, S. (2017). The Effect of Social Rewards and Perceived Effectiveness of e-Commerce Institutional Mechanisms on Intention to Group Buying. In Advances in Human Factors, Business Management, Training and Education. 833-840.

Lutfi, M.,Nazwar, C., and Muda, I (2016). Effects of investment opportunity set, company size and real activity manipulation of issuers in Indonesia Stock Exchange on stock price in Indonesia. International Journal of Economic Research. 13(5). 2149-2161.

McKnight, D. H., Lankton, N. K., Nicolaou, A., \& Price, J. (2017). Distinguishing the effects of B2B information quality, system quality, and service outcome quality on trust and distrust. The Journal of Strategic Information Systems, 26(2). 118-141.

Mendoza, Virginia, Beatriz Pico González, Eleuterio Cornelio Aquiahuatl. (2011). Human approach in the quality management system of manufacturing SMEs in Mexico Theoretical review and proposal of a conceptual model. Contaduría y Administración 58(2). 113-133.

Muda, I and A. A. F. Hutapea. (2018). Influence of capital expenditure and income original region to the income per capita in Indonesia. IOP Conference Series: Earth and Environmental Science. 2018. 126 doi:10.1088/17551315/126/1/012065.

Muda, I and A.Dharsuky. (2015). Impact of Region Financial Information System (SIKD) Quality, Role Ambiguity And Training on Precision of Financial Statement of Local Government Presentation In North Sumatra. International Journal of Applied Business and Economic Research, 13(6). 4283-4304.

Muda, I, (2017). The Effect of Allocation of Dividend of the Regional Government-Owned Enterprises and the Empowerment Efforts on the Revenue of Regional Government: The Case of Indonesia. European Research Studies Journal. XX(3A). 223-246.

Muda, I, (2017). The Effect of Supervisory Board Cross-Membership and Supervisory Board Members' Expertise to The Disclosure of Supervisory Board's Report : Empirical Evidence From Indonesia. European Research Studies Journal. XX(3A). 702-716.

Muda, I,and Erlina, (2018). Performance Appraisal of Government Internal Supervisory Apparatus (APIP) in Implementation of Compliance Audit at Inspectorate of Medan City, Indonesia, International Journal of Civil Engineering and Technology, 9(5), 1347-1359.

Muda, I, D.Y.Wardani, Erlina, A.Maksum, A.F.Lubis and R.Bukit. (2017). The Influence of Human Resources Competency and The Use of Information Technology on The Quality of Local Government Financial Report with Regional Accounting System as an Intervening. Journal of Theoretical and Applied Information Technology. 95(20). 1432-1451.

Muda, I, Dharsuky. A., Siregar, H.S., and Sadalia, I. (2017). combined loading and Cross-dimensional loadings timeliness of presentation of financial statements of local government. IOP Conference Series : Materials Science and Engineering. 180. doi: 10.1088/1757-899X/180/1/012099.

Muda, I, Erlina, I.Yahya and A.A.Nasution, (2018). Performance Audit and Balanced Scorecard Perspective, International Journal of Civil Engineering and Technology, 9(5), 1321-1333.

Muda, I, F.Roosmawati, H.S Siregar, Ramli, H.Manurung \& T.Banuas. (2018). Performance Measurement Analysis of Palm Cooperative Cooperation with Using Balanced Scorecard. IOP Conference Series : Materials Science and Engineering 2017.288.

Muda, I, M.Ismail and Marhayanie. (2017). Impact Allocation Capital Expenditure on The Improvement of the Local Government Assets in North Sumatra and Effect on Local Revenue Sustainability. International Journal of Economic Perspectives. 11(2). 151-164. 
Muda, I, M.Sihombing, E.Jumilawati and A.Dharsuky. (2016). Critical Success Factors Downstream Palm Oil Based Small And Medium Enterprises (SME) In Indonesia. International Journal of Economic Research. 13(8). 35313538 .

Muda, I, Rahmanta, S. Adi and Marhayanie. (2017). The Role of Working Capital, Productivity, Applied Technology and Selling Market Prices on Fisherman's Revenues. International Journal of Economic Research. 14(16). 291302.

Muda, I,, H.S Siregar, S.A Sembiring, Ramli, H.Manurung \& Z.Zein. (2018). Economic Value of Palm Plantation in North Sumatera and Contribution to Product Domestic Regional Bruto. IOP Conference Series : Materials Science and Engineering 2017. 288.

Muda, I., \& A. N. Hasibuan. (2018). Public Discovery of the Concept of Time Value of Money with Economic Value of Time. Emerald Reach Proceedings Series. 1.255-261.

Muda, I., \& Nurlina. (2018). Influence of Manufacture of Textiles, Clothing and Leather and Manufacture of Paper, Printing and Publishing to The Economic Growth. Emerald Reach Proceedings Series. 1.105-111.

Muda, I., \& Windari. (2018). Dimension of an Islamic Model Value on the Existence of Syariah Waltmart. Emerald Reach Proceedings Series. 1.321-326.

Muda, I., A. H. Harahap, Erlina, S.Ginting, A.Maksum \& E.Abubakar. (2018). Factors of quality of financial report of local government in Indonesia. IOP Conference Series: Earth and Environmental Science. 2018.

Muda, I., Panjaitan, S.R, Erlina, S. Ginting, A. Maksum \& E. Abubakar. (2018). Model application of Murabahah financing acknowledgement statement of Sharia accounting standard No 59 Year 2002. IOP Conference Series: Earth and Environmental Science. 2018. 126

Muda, I., Sidauruk, S.H., Siregar, H.S., Nurzaimah. (2018). The effect of corporate social responsibility on company's value with common effects model (CEM), fixed effects model (FEM) and random effects model (REM) approaches (empirical evidence in Indonesia stock exchange). QualityAccess to Success. 19(165). 79-90.

Muda, I.,\& R.Naibaho. (2018). Variables influencing allocation of capital expenditure in Indonesia. IOP Conference Series: Earth and Environmental Science. 2018. 126.

Muda, I.Dharsuky, A.,Sadalia, I., and Siregar, H.S. (2016).Impact of capital investments and cash dividend policy on Regional Development Bank (BPD) PT. Bank Sumut to the district own source revenue and economic growth. International Journal of Applied Business and Economic Research. 14(11). 7863-7880.

Muda, I; M. Weldi; Siregar, H.S, \& Indra, N. (2018). The Analysis of Effects of Good Corporate Governance on Earnings Management in Indonesia with Panel Data Approach. Iranian Economic Review. 22(2). 657-669.

Muda,I,Rahmanta, Marhayanie \& A.S. Putra. (2018). Institutional Fishermen Economic Development Models and Banking Support in the Development of the Innovation System of Fisheries and Marine Area in North Sumatera. IOP Conference Series : Materials Science and Engineering. 2017.288.

Muda; I, S. H. Sidauruk, H. S. Siregar, Nurzaimah. (2018). The Effect of Corporate Social Responsibility on Company's Value with Common Effects Model (CEM), Fixed Effects Model (FEM) and Random Effects Model (REM) Approaches (Empirical Evidence in Indonesia Stock Exchange). QualityAccess to Success. 19(165). 94-102.

Nasution, D. A. D. (2016). Analysis of Factors Affecting Implementation of Accrual-Based SAP with SKPD Commitment as Moderating Variables at North Sumatera Provincial Government. Thesis. University of North Sumatra.

Noutsa, F. A., Kamdjoug, J. R. K., \& Wamba, S. F. (2017). Acceptance and Use of HRIS and Influence on Organizational Performance of SMEs in a Developing Economy: The Case of Cameroon. In World Conference on Information Systems and Technologies. 45(2). 563-580.

Nurlina and Muda, I. (2017). The Analysis of The Effects of Capital Expenditure and Human Development Index on Economic Growth and Poverty in East Aceh Regency. International Journal of Economic Research. 14(16). 395409.

Nurzaimah, Rasdianto and Muda, I. (2016). The skills and understanding of rural enterprise management of the preparation of financial statements using Financial Accounting Standards (IFRs) financial statement on the Entities without Public Accountability (ETAP) framework on the implementation of village administration law. International Journal of Applied Business and Economic Research. 14(11). 7417-7429. 
Oakland, T., \& Harrison, P. L. (Eds.). (2011). Adaptive behavior assessment system-II: Clinical use and interpretation. New York. Academic Press.

Orlikowski W dan D.C. Gash (1991). Changing frames: understanding technological changes in organisations. Working Paper 236, Massachusetts Institute of Technology, Cambridge, MA.

Petter, S., DeLone, W., \& McLean, E. R. (2013). Information systems success: The quest for the independent variables. Journal of Management Information Systems, 29(4). 47-62.

Pohan., N., Badaruddin., R.F Dalimunthe., A. Purwoko., \& Muda, I., (2018). The Effects of Human Resource Development and Institutional Arrangements on Performance, Service Quality and Area Development in Indonesia. QualityAccess to Success. 19(163). 94-102.

Price, J. A., Morris, Z. A., \& Costello, S. (2018). The Application of Adaptive Behaviour Models: A Systematic Review. Behavioral Sciences, 8(1), 11.

Radu, A. C., Orzan, M. C., Ceptureanu, S., \& Stoica, I. (2017). User Satisfaction Regarding Healthcare Education Services Financed Through The European Social Fund. Economic Computation \& Economic Cybernetics Studies \& Research, 51(1). 177-189.

Ren, Ji-fan, S., Fosso Wamba, S., Akter, S., Dubey, R., \& Childe, S. J. (2017). Modelling quality dynamics, business value and firm performance in a big data analytics environment. International Journal of Production Research, 55(17), 5011-5026.

Rostaminezhad, M. A., Mozayani, N., Norozi, D., \& Iziy, M. (2013). Factors related to e-learner dropout: Case study of IUST elearning center. Procedia-Social and Behavioral Sciences, 83, 522-527.

Rust, J. O., \& Wallace, M. A. (2004). Book review: Adaptive behavior assessment system. Journal of Psychoeducational Assessment, 22(4), 367-373.

Ryu, K., \& Lee, J. S. (2017). Examination of restaurant quality, relationship benefits, and customer reciprocity from the perspective of relationship marketing investments. Journal of Hospitality \& Tourism Research, 41(1), 66-92.

Sadalia, Isfenti. N.A.B.Rahamani \& Muda, I. (2017). The Significance of Internet Based Financial Information Disclosure on Corporates' Shares in Indonesia. International Journal of Economic Research. 14(12), 337-346.

Sadalia, Isfenti, M. H. Kautsar, N. Irawati and I, Muda. (2018). Analysis of the efficiency performance of Sharia and conventional banks using stochastic frontier analysis. Banks and Bank Systems, 13(2), 27-38. doi: 10.21511/ bbs.13(2).2018.03

Sánchez, Héctor Horacio Garza, Klender Aimer Cortez Alejandro, Alma Berenice Méndez Sáenz, Martha Pilar Rodríguez García. (2017). Effect of information quality due accounting regulatory changes: Applied case to Mexican real sector. Contaduría y Administración 62, 761-774.

Sari, M; A. F. Lubis; A. Maksum; P. Lumbanraja \& I. Muda. (2018). The Influence of Organization's Culture and Internal Control to Corporate Governance and Its Impact on BUMN (State-Owned Enterprises) Corporate Performance In Indonesia, Journal of Applied Economic Sciences. 4(58), 562 - 575.

Seddon.P.B., \& Kiew, M. Y. (1996). A Partial Test and Development of DeLone and McLean's Model of IS Success. Australian Journal of Information Systems, 4(1), 90-109.

Sforza, V., \& Cimini, R. (2017). Central government accounting harmonization in EU member states: will EPSAS be enough?. Public Money \& Management, 37(4), 301-308.

Shang, S. S., Wu, Y. L., \& Li, E. Y. (2017). Field effects of social media platforms on information-sharing continuance: Do reach and richness matter?. Information \& Management, 54(2), 241-255.

Shin, D. H., \& Biocca, F. (2017). Health experience model of personal informatics: The case of a quantified self. Computers in Human Behavior, 69, 62-74.

Sihombing, M, Muda, I, E.Jumilawati \& A.Dharsuky. (2017). Factors Affecting The Success of Local Innovation Systems with Government Programs As Moderators. International Journal of Economic Research. 14(21). 272-289.

Sirojuzilam, Hakim, S., and Muda, I. (2016). Identification of factors of failure of Barisan Mountains Agropolitan area development in North Sumatera- Indonesia. International Journal of Economic Research. 13(5). 2163-2175.

Sirojuzilam, Hakim, S., and Muda, I. (2017). Effect of Private Collaborative as a Moderation of Success of Agropolitan Program. International Journal of Economic Research. 14(16). 304-315. 
Situmorang, S.H, E.S. Rini \& Muda, I. (2017). Customer Experience, Net Emotional Value and Net Promoter Score on Muslim Middle Class Women in Medan. International Journal of Economic Research. 14(20). 269-283.

Sun, J., \& Teng, J. T. (2017). The construct of information systems use benefits: Theoretical explication of its underlying dimensions and the development of a measurement scale. International Journal of Information Management, 37(5). 400-416.

Syahyunan, Muda I, Siregar, H.S, Sadalia,I. \& Chandra G. (2017). The Effect of Learner Index and Income Diversification on The General Bank Stability In Indonesia. Banks and Bank Systems. 12(4). 171-184.

Tam, C., Tam, C., Oliveira, T., \& Oliveira, T. (2017). Understanding mobile banking individual performance: The DeLone \& McLean model and the moderating effects of individual culture. Internet Research, 27(3). 538-562.

Tarí, J. J., Pereira-Moliner, J., Pertusa-Ortega, E. M., López-Gamero, M. D., \& Molina-Azorín, J. F. (2017). Does quality management improve performance or vice versa? Evidence from the hotel industry. Service Business, 11(1). 23-43.

Tarmizi, H.B.,Daulay, M and Muda, I. (2016). The influence of population growth, economic growth and construction cost index on the local revenue of tax on acquisition of land and building after the implementation of law no. 28 of 2009. International Journal of Economic Research. 13(5). 2285-2295.

Tarmizi, HB., Daulay, M., and Muda, I. (2017). Impact of The Economic Growth and Acquisition of Land to The Construction Cost Index in North Sumatera. IOP Conference Series : Materials Science and Engineering. 180. doi: 10.1088/1757-899X/180/1/012004.

Uppal, M. A., Ali, S., \& Gulliver, S. R. (2017). Factors determining e-learning service quality. British Journal of Educational Technology. 89(2). 277-289.

Vischer, J. C., \& Wifi, M. (2017). The Effect of Workplace Design on Quality of Life at Work. In Handbook of Environmental Psychology and Quality of Life Research (pp. 387-400). Springer International Publishing.

Visinescu, L. L., Jones, M. C., \& Sidorova, A. (2017). Improving decision quality: the role of business intelligence. Journal of Computer Information Systems, 57(1),58-66.

Wang, E. S. T., \& Lin, R. L. (2017). Perceived quality factors of location-based apps on trust, perceived privacy risk, and continuous usage intention. Behaviour \& Information Technology, 36(1), 2-10.

Winter, Susan J.; Connie Marie Gaglio; \& Hari K. Rajagopalan. (2009). The Value of Information Systems to Small and Medium-Sized Enterprises: Information and Communications Technologies as Signal and Symbol of Legitimacy and Competitiveness. International Journal of E-Business Research, 5(1), 65-91.

Woodham, O. P., Williams, J. A., \& McNeil, K. R. (2017). Toward Understanding the Impact of Attributes on Satisfaction in Different Price Tiers. Journal of Consumer Satisfaction, Dissatisfaction and Complaining Behavior, 29, 28.

Yahya, I, Torong, Z.B., and Muda, I. (2017). Influence Behavior in Legislature Budget Development of Regions in the Province of Aceh and North Sumatra. International Journal of Economic Research. 14(8), 147-159.

Yang, F. X. (2017). Effects of restaurant satisfaction and knowledge sharing motivation on eWOM intentions: the moderating role of technology acceptance factors. Journal of Hospitality \& Tourism Research, 41(1), 93-127.

Yousuf, M. A., \& Wahab, E. B. (2017). The Role of Trust in the Relationship between Quality Factors and Customer Satisfaction in Mobile Banking: A Conceptual Framework. The Social Sciences, 12(4), 712-718.

Zerbino, P., Aloini, D., Dulmin, R., \& Mininno, V. (2017). Framing ERP Success from an Information Systems Failure Perspective: A Measurement Endeavor. Journal of Electronic Commerce in Organizations (JECO), 15(2), 31-47. 